\title{
Welfare State and Epistemic Communities of Fiscal Austerity in Brazil: from Lula da Silva to Jair Bolsonaro (2003-2020)*
}

\author{
Carlos Eduardo Santos Pinho (https://orcid.org/0000-0003-0657-8906)' \\ Programa de Pós-Graduação em Ciências Sociais, \\ Universidade do Vale do Rio dos Sinos, Porto Alegre, RS, Brasil.
}

\begin{abstract}
This article is based on a theoretical-conceptual framework and empirically grounded research to analyze the construction of discourse and institutional insertion of ideas from epistemic communities of fiscal austerity in Brazil, given the recent upsurge in liberal-orthodox policies and their repercussions for the welfare state. The study explores who these actors and institutions are, how they act, how they are organized, and who trains or finances them. The main objective is to unveil how the ideas in defense of fiscal constriction were formulated and disseminated, starting after the first term (2003-2006) of President Lula da Siva's government (2003-2010), when developmentalist policies replaced the neoliberal convention. The ideas of fiscal constriction were intensified during the government of President Dilma Rousseff (2011-2016), and gained characteristics of a unified proposal, materialized in the austerity program Uma Ponte para o Futuro (2015) (a bridge to the future). After President Rousseff's impeachment in 2016, policy-makers in the government President Michel Temer and his successor Jair Bolsonaro rapidly put forward the austerity program. The epistemic communities of fiscal austerity argue that the public policies outlined in the 1988 Brazilian Constitution are the main cause of the increase in spending on welfare, the accelerated growth of public debt, and the probable insolvency of the country.
\end{abstract}

KEYWORDS: Welfare State. Epistemic communities of fiscal austerity. 1988 Brazilian Constitution. Public policy. Brazil.

\section{Estado de bem-estar social e \\ "comunidades epistêmicas da austeridade fiscal" no Brasil: de Lula da Silva a Jair Bolsonaro (2003-2020)}

Resumo: A partir de aparato teórico-conceitual e de pesquisa empiricamente alicerçada, este artigo analisa a construção discursiva e a inserção institucional das ideias das "comunidades epistêmicas da austeridade fiscal" no Brasil, tendo em vista o recente recrudescimento de políticas liberal-ortodoxas e suas reverberações para o Estado do bem-estar social. Trata-se de investigar quem são esses atores e instituições, como atuam, como se organizam, por quem são formados ou financiados. O principal objetivo é descobrir como suas ideias em defesa da constrição fiscal foram formuladas e disseminadas, a partir do final do primeiro mandato (2003-2006) do governo Lula da Silva (20032010), quando da substituição da "convenção neoliberal" pela concepção desenvolvimentista, e intensificadas no governo Dilma Rousseff (2011-2016). Tal discurso adquiriu um caráter unificado no

\footnotetext{
* I would like to thank the anonymous reviewers of Revista Sociedade \& Estado and Colin Hay - Professor of Political Science at Sciences Po, Paris, and Director of Sheffield Political Economy Research Institute (SPERI) at the University of Sheffield, UK - for the attentive and rigorous reading, and for the criticisms, comments, and suggestions that contributed to improving this work. This article is the result of postdoctoral internship research, carried out between April 2017 and February 2019, at the National Institute of Science and Technology in Public Policies, Strategies, and Development (INCT/PPED), thanks to a grant from the Coordination for the Improvement of Higher Education Personnel (CAPES). The internship was carried out under the supervision of Professor Renato Raul Boschi of the Graduate Program in Political Science at the Institute of Social and Political Studies at the State University of Rio de Janeiro (IESP/UERJ),
} 
who coordinates the INCT/PPED with Professor Ana Celia Castro of the Institute of Economics at UFRJ. Previous versions of this manuscript were presented at the following scientific events:

i. IResearch Seminar of the Graduate Program in Public Policies, Strategies, and Development, at the Institute of Economics of the Federal University of Rio de Janeiro (IEPPED/UFRJ). UFRJ:

2018;

ii. XIV International Congress of the Brazilian Studies Association (Brasa). PUC-Rio: 2018 and

iii. 2nd Seminar NUPPAA (Nucleus of Public Policies: Analysis and Evaluation)- Thinking and Rethinking Public Policies, from the National Institute of Science and Technology in Public Policies, Strategies, and Development (INCT/PPED). Brazilian College of Higher Studies/UFRJ: 2017.

I. Carlos Eduardo Santos Pinho is professor and researcher on the Graduate Program in Social Sciences at the University of Vale do Rio dos Sinos (PPGCS-UNISINOS). Ph.D. and master degree in Political Science from IESP/ UERJ, Postdoctoral internship at INCT/PPED with a scholarship from Capes, and Fellow programa de austeridade "Uma ponte para o futuro" (2015), foi sacramentado na ruptura democrática de 2016 e implementado com celeridade pelos policy-makers dos governos Michel Temer e Jair Bolsonaro. As "comunidades epistêmicas" argumentam que as políticas públicas preconizadas na Constituição Federal de 1988 são a principal causa da elevação dos gastos com bem-estar, do crescimento acelerado da dívida pública e da provável insolvência do Estado brasileiro.

Palavras-chave: Estado de bem-estar social. Comunidades epistêmicas da austeridade fiscal. Constituição Federal de 1988. Políticas públicas. Brasil.

\section{Introduction}

7

his article analyzes the construction of discourse and institutional insertion of ideas of epistemic communities of fiscal austerity in Brazil and their repercussions for the country's (incipient and currently endangered) welfare state. These epistemic communities are composed of large corporatist press and oligopolistic media, industrial entrepreneurs, orthodox economists, liberal-conservative parliamentary coalition, and sectors of the middle and upper classes who engaged in the demonstrations demanding the impeachment of President Rousseff in 2016. This study demonstrates how these ideas have unified around a liberal-conservative political-economic coalition that has governed Brazil since the 2016 democratic break and how they have influenced the Brazilian state regarding macroeconomic policy and implementation of public policies.

In addition to analyzing the epistemic communities' discourse and practices, this reflection highlights the challenges of implementing welfare policies within financial globalization. In this context, financial intermediaries greatly benefit from taxpayers' money. These resources are massively used to fund public debt rather than public investment, which means that large sums of public money end up with shareholders, financial institutions, and financial market investors. There is an immediate and short-term perspective of valuing financial investment to the detriment of production and policies that streamline the economy, such as public investment in well-being and infrastructure, household consumption, and business investment. Financialization is the mechanism through which money is channeled from savers (investors) to borrowers (families, companies, governments), and this mechanism imposes the austerity regime in Brazil (Davis \& Kim, 2015; Dowbor, 2017; Streeck, 2019).

Because of the structural contingencies imposed by financial globalization, the Workers Party (PT) governments expressed concern about fiscal austerity. The primary fiscal surplus target in the first government of President Lula da Silva jumped from $3.75 \%$ to $4.25 \%$ of GDP. In this sense, it was as strict as President Cardoso's previous government, known for its orthodox measures (Pinho, 2019). In 2011, 
President Rousseff started her term with a contractionary fiscal policy, reducing credit, and increasing interest rates. This stagnated GDP between the second half of 2011 and the first half of 2012 (Bastos, 2017). Around August 2012, Rousseff adopted a model of productive development based on fiscal expansion through the so-called new macroeconomic matrix, as opposed to the immediatist perspective of financial capital. However, the model faced the political-economic elites' resistance, and a severe fiscal (spending cut) and monetary (increase in interest rate to fight inflation) adjustment was adopted in 2015. The president's heterodox experiment contradicted several interests, especially those of the financial sector and neoliberal ideologists, who came to play an important role in the parliamentary coup of 2016. Later, these same actors integrated the economic bureaucracy of Michel Temer (2016-2018) and Jair Bolsonaro's (2019 - current) governments.

The context that preceded the 2016 impeachment was marked by intense political instability. Aécio Neves (Brazilian Social Democracy Party - PSDB), the defeated candidate in the 2014 presidential elections, unexpectedly asked the Superior Electoral Court (TSE) for a recount of votes. The president of the Chamber of Deputies, Eduardo Cunha (at that time, member of the Party of the Brazilian Democratic Movement - PMDB of the State of Rio de Janeiro, which recently changed its denomination removing the word "Party" - MDB), put in the parliament's agenda a series of controversial issues, such as labor outsourcing regulation ( $P L$ 4330/04). Also, he led the parliament in approving extra expenses for public servants and pensioners, jeopardizing Rousseff's fiscal adjustment policies (O Estado de S. Paulo, February 24, 2016; G1, October 30, 2014).

Against this backdrop, the questions addressed in this study are:

i. What are epistemic communities of fiscal austerity, when were they formed, and how were they organized, systematically disseminating the rhetoric that social welfare spending is incompatible with the country's GDP?

ii. How were epistemic communities' ideas ${ }^{1}$ inserted in the 1988 Brazilian Constitution during Michel Temer and Jair Bolsonaro's governments, and what are their impacts?

This study seeks to offer an original contribution to the public and academic debate, fill a gap in the literature, and advance knowledge about the political economy of public policies. The hypothesis suggested is that, from the end of President Lula da Silva's (2003-2010) first mandate, in 2006, until the deposition of Dilma Rousseff (2011-2016) through a parliamentary coup d'État, an epistemic community of fiscal of the Graduate Program in Political Sociology at the Darcy Ribeiro State University of Northern Rio de Janeiro (PPGSPUENF) with a scholarship from Research Support Foundation for the State of Rio de Janeiro (Faperj). Associate Researcher at INCT/PPED and member of the Cycle of Higher Studies Futures of Social Protection, coordinated by Professor Sonia Fleury, Senior Researcher at the Center for Strategic Studies of the Oswaldo Cruz Foundation (CEE-

Fiocruz).

<cpinho19@unisinos. br>.

1. According to Vivien Schmidt, the discourse is not just about ideas or text, but also about the context in which ideas are developed and promoted (Schmidt, 2008 apud Ladi, Lazarou \& Hauck, 2018). 
austerity was formed and emphatically disseminated the neoliberal prescription that the 1988 Constitution is no longer compatible with the capacity of the Brazilian state budget. Policy-makers inserted these ideas of the epistemic community in the country's constitution through amendments, and they were rapidly implemented during the governments of President Michel Temer and successor Jair Bolsonaro.

Including this introduction, the article is divided into five sections. The second section examines the successes and limits of the new democratic developmentalism (2003-2016) to implement the policy framework set out in the 1988 Brazilian Constitution. The third section explores who are the epistemic communities of fiscal austerity and their characteristics, followed by the fourth section with an analysis of how the ideas of these epistemic communities were inserted in the constitution under the governments of Michel Temer and Jair Bolsonaro. The fifth and last section presents the final considerations.

\section{The socio-political meaning of the 1988 Brazilian Constitution:} advances and limitations of the new democratic developmentalism (2003-2016)

In contrast to the excluding legacy of authoritarian national-developmentalism (1964-1985) (Pinho, 2019; 2020), the promulgation of the 1988 Brazilian Constitution reflected the struggle for a new comprehensive model of social protection. This model had an original component of social mobilization to expand social rights as part of the transition to democracy. In addition to the challenge of increasing social inclusion and combating poverty, the construction of new democratic and inclusive institutions began in an environment of accumulation of external and internal public debt. This process was marked by the primacy of conventional orthodoxy and pressure from international agencies (such as the International Monetary Fund - IMF) to cut spending, privatize public services, reduce the state's size, and limit its power. The mobilization of social movements was crucial to include public pension, health, and social assistance as part of a comprehensive notion of social security, formalizing the concept of universal social rights as a fundamental part of citizenship (Fleury \& Pinho, 2018).

Between 2003 and 2014, Brazil witnessed the most significant reduction in absolute poverty in almost four decades. This achievement was possible through a political strategy of increasing formal employment and increasing the weight of salaries in the economy by recovering the minimum wage's real value, equivalent to more than $110 \%$ appreciation over two decades, with 70\% appreciation between 20042014. The number of formal workers earning a minimum wage increased from 2.5 
million to 15 million from 1995 to 2014. Social security benefits linked to the minimum wage went from 10 to 20 million beneficiaries in the same period. While guaranteeing social rights, universal policies, and increased levels of well-being, the 1988 constitution did not structurally change wealth distribution patterns. The regressive tax framework prevailed, and the possibility of implementing a progressive tax system was vetoed at the 1987 Constituent Assembly (Arretche, Marques \& Faria, 2019; Kerstenetzky, 2017).

The limitations and uniqueness of the new democratic developmentalism (20032016) result from this scenario. The approach refers to a social-democratic strategy that did not promote structural reforms and sought to change the excluding characteristics of Brazilian capitalism while respecting the political party competition logic (Roberts, 2008). In addition to establishing alliances with political and social forces such as leftist parties, the progressive middle class, unions, and social and workers movements, it was inevitable to ally with archaic, conservative, and reactionary political elites in order to obtain governability in the context of the coalition presidentialism (Abranches, 2018). The social dimension gained prominence. There was an expansion of access to the domestic mass consumption market, unlike what was observed in the exclusive model of authoritarian national developmentalism (1964-1985) and the pro-market reforms (that occurred from 1990 to 2002). In the pro-market reforms, social policies were submitted to the logic of fiscal austerity and monetary stabilization (Pinho, 2019).

\section{The power of (unison) ideas voiced}

\section{by epistemic communities of fiscal austerity}

This section examines the role of the ideas put forward by the epistemic communities of fiscal austerity. However, it is first important to clarify the concept of epistemic communities. For the political scientist Peter Haas, an epistemic community is a network of professionals with knowledge and skills recognized in a specific field, able to subsidize policy implementation. Although the epistemic community gathers professionals with different backgrounds, these participants share

i. a set of normative beliefs and principles that offer a value-based foundation for collective social action;

ii. causal beliefs that contribute to understanding the multiple links between possible political actions and desired results;

iii. notions of validity that are intersubjective criteria for validating knowledge in their domain of experience; and 
iv. a set of practices associated with an archetype of problems they have the professional ability to tackle. These professionals presumably engage in solving these problems because they believe their action contributes to improving human well-being (Haas, 1992).

The theoretical-conceptual framework above helps characterize, systematize, and operationalize this research object, both analytically and empirically. It indicates that, despite the differences and singularities of the epistemic communities of fiscal austerity in Brazil, they share the unequivocal belief that monetary stability and strict control of public spending are the paths to sustained growth and economic development. For these communities, the growth in public indebtedness suggests that austerity is the only alternative to avoid the Brazilian state's insolvency, even if this implies de-constitutionalizing social rights and constitutionalizing fiscal austerity. Therefore, it is crucial to understand, who are the actors and institutions within these epistemological communities? How do they work, and how are they organized? Who trains or finances them? What is their ability to influence the formulation and implementation of policies? The following section characterizes each of the epistemological communities.

\section{Large corporativist press and oligopolistic media}

The mainstream Brazilian media is connected to the global networks of power, wealth, and technology (Castells, 1999). It receives funding from advertisers that constitutes major financial, commercial, and industrial corporations and obtains tax exemptions and government incentives. Numerous editorials and articles reproduce the neoliberal rhetoric of common knowledge. By lacking scientific and analytical rigor, large national newspapers recognize that, in the 2002 election campaign, Lula da Silva was successful in spreading a document entitled Carta ao povo brasileiro (Letter to the Brazilian People), in which he promised to control inflation and demonstrate to financial market investors the commitment to continue and deepen the fiscal austerity policies of the previous government (Fernando Henrique Cardoso, 1995-2002). After his election, President Lula da Silva successfully put together a liberal-orthodox economic team, led by Antonio Palocci, in the Ministry of Finance, and Henrique Meirelles, in the Central Bank. The team strictly followed the premises of economic stabilization. These premises included high-interest rates to control inflation, fluctuating exchange rates, and an increase in the public sector's primary surplus from $3.75 \%$ to $4.25 \%$ of GDP, surpassing the primary surplus target adopted during President Cardoso's government. During the first term of Lula da Silva's government (2003-2006), the public sector pension reform was approved. It was the same reform the previous government tried and failed to carry out. Howev- 
er, in his second term, with Dilma Rousseff as Chief of Staff, the interventionist and developmentalist manuals of the Workers' Party were implemented, contributing to the disastrous heterodox economic policy of the new macroeconomic matrix. According to the large corporatist press and the oligopolistic media as epistemic communities, Lula da Silva and Dilma Rousseff used the worsening of the 2008 international systemic financial crisis - generated with the bursting of the United States housing bubble - as an argument to adopt an uncontrolled increase in public spending. Thus, Lula da Silva and Rousseff laid the foundations for the biggest fiscal crisis in the country's history (O Globo, September 17, 2015, February 23, 2017, April 01, 2017).

Therefore, this epistemic community used the argument of combating the corruption of the developmentalist governments and halting public debt growth to justify its support to the democratic rupture in 2016. The large corporatist press also sustained the intensification of austerity policies carried out by President Michel Temer and his successor Jair Bolsonaro. The editorial of one of the largest newspapers in the country, Folha de S. Paulo, offers strong evidence of this dynamic:

\begin{abstract}
It is essential to containing the increase in public debt and economic degradation. Spending cuts will have to be made with unprecedented radicalism, lest even worse nightmares become a reality, such as the specter of uncontrolled inflation. [...] Dramatic circumstances also demand a partial and temporary release of compulsory health and education expenditures, which would be accompanied by a careful review of these expenditures in the future [...] The country, however, has no choice. President Dilma Rousseff, too: she will have no choice if she falls under the weight of the crisis, but to abandon her presidential responsibilities and, eventually, her position (Folha de S. Paulo, Set. 2015).
\end{abstract}

\title{
Industrial entrepreneurs
}

A conciliatory stance toward industrial entrepreneurs marked the mandates of President Lula da Silva (PT) (2003-2010). In order to stabilize the currency, the previous government - Fernando Henrique Cardoso (PSDB) (1995-2002) - adopted fiscal (cut in public spending) and monetary (increase in interest rate) policies that penalized these entrepreneurs. President Lula worked to get closer to the productive sector, starting by choosing a businessman of the textile sector, José Alencar, as his vice-president. Also, the former president created the Economic and Social Development Council (CDES), gathering the main players of the national industry. During Lula's second term, the government counted on a virtuous cycle of economic growth to boost public investment in infrastructure, promoting a resumption of the 
2. President

Rousseff's second mandate was abbreviated due to an impeachment process. The Brazilian Senate approved the process and suspended Rousseff's powers in May 2016.

\section{To bail out} capital and ensure the recovery of profit rates in the non-financial sector of the economy, such measures

- implemented without democratic control or guarantees of return to society - converged to leverage the dismantling of the social security budget financing (Salvador, 2017).

4. Fiesp used the image of a yellow rubber duck as a symbol of its campaign. In its headquarter, the federation installed a giant inflatable yellow duck, which became famous as a symbol of the industry's resistance to increasing the tax burden. It was also adopted as a symbol of the general dissatisfaction with President Rousseff's government, used in the demonstrations asking for her impeachment. The yellow duck refers to an expression in Portuguese - pagar o pato - which is the equivalent of being a scapegoat, i.e., being punished for another's faults or actions. In this case, Fiesp's campaign claimed industrial policy. Some examples of policies are the Growth Acceleration Program (PACI and II), the Policy on Industry, Technology, and Foreign Trade (PITCE - 20032007), and the Productive Development Policy (PDP - 2008-2010) (PINHO, 2019).

However, the following president, Dilma Rousseff (PT) (2011-2016)², faced an adverse international and macroeconomic environment - Eurozone crisis and a slowdown in the commodities boom - and did not keep the same level of public investment. The economic model implemented in 2012 and deepened in 2014 was the so-called Agenda Fiesp (Fiesp stands for the Federation of Industries of the State of São Paulo) (Carvalho, 2018) or the new macroeconomic matrix. The model adopted measures such as interest reduction, tax exemptions through tax waivers of billions of Brazilian reais ${ }^{3}$, expansion of credit from the National Development Bank (BNDES), and freezing electricity tariffs. The policies' results were ineffective due to economic slowdown and fiscal deterioration (Boschi \& Pinho, 2019a; 2019b).

In October 2015, Vice President Michel Temer, before his official break with President Rousseff's government, released the document Uma ponte para o futuro (a bridge to the future) (2015). The text would become his government platform (and the platform of the current president Jair Bolsonaro). As explained below, the platform contains a set of austerity measures aimed at deepening pro-market reforms (1990-2002) (Pinho, 2019).

Michel Temer approached the business community and obtained the support of several class associations in the impeachment process of President Dilma Rousseff. Among the organizations supporting the process were the Federation of Industries of the State of São Paulo (Fiesp), the Federation of Industries of the State of Rio de Janeiro (Firjan), the Brazilian National Confederation of Industry (CNI), the Federation of Commerce of the State of São Paulo (Fecomércio). Fiesp launched in 2015 a campaign ${ }^{4}$ against CPMF, a tax on financial transactions implemented to cover the deficit in the federal budget. Fiesp's president, Paulo Skaf, asked Congress's support for the federation's campaign, which expanded its scope and took an important role in President Rousseff's impeachment process (Boschi \& Pinho, 2019a; 2019b). Fiesp not only advocated the extinction of the CPMF but demanded fiscal adjustment with government cuts and a commitment to not increasing the tax burden. In Paulo Skaf's words:

Since she did not resign as we asked, from now on, we are asking for impeachment. It is unacceptable that Brazil is adrift. There is a total lack of control, and the government is not concerned with companies, with unemployment, only with remaining in power $(O$ Globo, March 17, 2016). 
Elected in 2002 and inaugurated in 2003, the government of President Lula da Silva appointed liberal-orthodox economists to the central positions of the economic bureaucracy, such as the Central Bank (Henrique Meirelles), the Ministry of Finance (Antonio Palocci). President Lula da Silva actually deepened fiscal austerity policies initiated in the previous government. Henrique Meirelles, BankBoston's former president, was elected federal deputy running for PSDB (political party rival to President Lula's PT) and received full government approval and independence to assemble his team. Meirelles preserved many of the Central Bank's directors who had served in the previous government, such as Beny Parnes, Alexandre Schwartsman, and Ilan Goldfajn. These directors were experienced orthodox economists with close ties to the financial system and had committed to international investors to continue President Cardoso's macroeconomic policies. It is worth mentioning the also orthodox economists Joaquim Levy and Marcos Lisboa, respectively, secretary of the treasury and secretary of economic policy, who were trained in universities in the US, and had experience in the private sector and multilateral institutions (Campello, 2015).

At the end of 2005, the neoliberal convention (Erber, 2011) lost space in Lula's government, and the developmentalist approach emerged. In this period, Dilma Rousseff was appointed Chief of Staff, Guido Mantega took office as Ministry of Finance replacing Antônio Palocci, and Luciano Coutinho took office as President of BNDES, promoting negotiations among the industry, construction conglomerates, and the productive sector. In addition, the role of state-owned banks and enterprises gained importance again after having lost relevance during the government of President Cardoso (1995-2002) (Loureiro, Santos \& Gomide, 2011). The change of path in Lula's macroeconomic policy led to fiscal expansion, deepened by Dilma Rousseff's new macroeconomic matrix (2011-2016), triggered countless criticisms in the mainstream press through news articles signed by orthodox economists ${ }^{5}$ (Pinho, 2019).

These neoliberal economists and ideologists working for different governments, think tanks, consulting companies, and multilateral organizations point out that the negative changes in fiscal institutions started in President Lula's second mandate (2007-2010). For these professionals, the previous reforms in the 1980s and 1990s granted Brazilian public finances a high institutional standard, marked by the acceptance of austerity policies put forward by the International Monetary Fund (IMF) and the Fiscal Responsibility Law (LRF/2000). The changes in fiscal institutions intensified after the 2008 global financial crisis when the government interpreted the industry should not pay the price for bad government spending.

5. Brazilian liberal and conservative think tanks such as the Brazilian Institute of Economics (Ibre) and the Fernand Braudel Institute (IFB) are linked to businesses and financial markets and advocate fiscal adjustment. Other think tanks such as the Institute of Applied Economic Research (Ipea) and the InterUnion Department of Statistics and Socioeconomic Studies (Dieese), advocate countercyclical policies and increased public social spending in times of crisis (Ladi, Lazarou \& Hauck, 2018) 
the crisis as a sign of pro-market policies' failure. In the conception of the epistemic communities of orthodox economists (or monetarists), Dilma Rousseff's disastrous developmentalist experience and practices - named creative accounting - affected fiscal institutions' robustness. The deterioration of public accounts jeopardized businesses and the financial market's trust, repressing investment, paralyzing projects, and reducing the country's credit rating. The PT governments' policy of constantly valuing the minimum wage above labor productivity reduced the expected profits and decapitalized companies, increasing their costs. This phenomenon had a negative impact on economic growth by increasing current public spending (Mendes, 2014; Nóbrega, 2016; Salto \& Almeida, 2016; Tollini, 2016).

The Independent Fiscal Institution (IFI) is an agency created to monitor Brazil's fiscal and budgetary activities. Its executive director is economist Felipe Scudeler Salto. According to the IFI, spending on pension and benefits, education, health, and social assistance represents $75 \%$ of the Union budg excluding debt services. The debt will correspond to $93.3 \%$ of GDP in 2024 and $85.5 \%$ of GDP by 2030 . However, this evolution will depend heavily on the capacity to stop the growth of government expenditure in order to contain the expansion of debt and the probable insolvency of the Brazilian State (IFI, 2017).

\section{CHART 1}

6. This scenario was prepared before the Covid-19 pandemic. It suggests recession/ depression and low interest rates. However, interest rates in Brazil are still among the highest in the world. According to the ranking released by Infinity Asset and Money You, on May 22, 2020, considering figures of 40 countries, Brazil ranks tenth in the nominal interest and eighth in real interest rate $(O$ Estado de S. Paulo, June 03, 2020). After the pandemic, the projections for the growth of the debt shown in Graph 1 are maintained.
GROSS GOVERNMENT DEBT (GGD) IN \% OF GDP AND PRIMARY RESULT IN CURRENT BRL BILLIONS (RIGHT AXIS) - 2017/20306

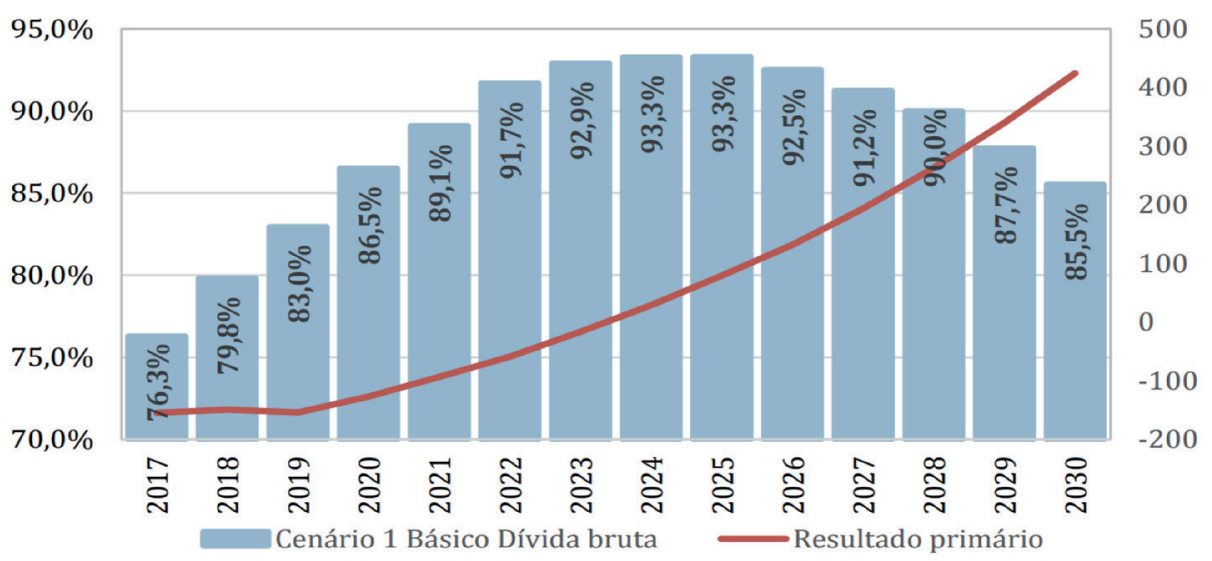

Source: Instituição Fiscal Independente (2017) (Independent Fiscal Institution)

Statements about the unsustainability of the public debt carry an ideological or moral bias, typical of most neoliberal assumptions when associating debt with sinas the German sociologist, Max Weber (2004), showed in the classic The protestant 
ethic and the spirit of capitalism. There is controversy in the political economy literature about the supposed exacerbated nature of the Brazilian public debt.

Different from liberal and monetarist economists mentioned above, who advocate cutting spending on welfare to ensure fiscal balance, some Marxist economists argue that the social security retraction is a consequence of tax breaks on social contributions, reduction of payroll costs, decrease in public revenue, as well as amortization of public debt, which are measures that favor speculative investment and the rentier and financial capital (Salvador, 2017).

\section{Liberal-Conservative Parliamentary Coalition}

Dilma Rousseff (PT) was reelected in the 2014 presidential elections, defeating Aécio Neves (PSDB) by a small margin of votes. In the same electoral process, Brazilians elected "the most conservative Congress of the period post-1964" (O Estado de S. Paulo, October 06, 2014, our translation) - which comprises the years of the military dictatorship and the period of re-democratization. In the 2014 elections, the parliamentary front related to unions shrank from 86 to 46 federal deputies. Recent data from the Inter-Union Parliamentary Advisory Department (Diap) showed that the 2018 elections reinforced this trend. The elected Congress can be characterized as (1) liberal, from an economic point of view, (2) fiscalist, regarding public management, (3) conservative, in terms of moral and religious values, (4) more right-wing, from an ideological point of view, and (5) lagging behind regarding the environment and human rights. As for the elected policymakers' ideological profile, social class, and themes of interest, the conservative bias and the growth in the number of right-wing politicians in Congress are clear. The number of policymakers from the working class largely reduced, whereas the evangelical parliamentary front and the parliamentary front pro-gun rights (known as bancada da bala) gained members and strength. Also, newly elected policymakers reinvigorated the agricultural and business parliamentary fronts. In the Chamber of Deputies, the increase in the number of right-wing deputies stood out. The group was formed by 210 deputies representing the following parties: PSL (Social Liberal Party), DEM (Democrats), PP (Progressives), PR (Party of the Republic), PRB (Brazilian Republican Party), PSC (Social Christian Party), Novo (New Party), Patriota (Patriot), PRP (Progressive Republican Party), PTC (Christian Labor Party), and DC (Christian Democracy).

Despite having lost some members, as in the case of the agricultural parliamentary group, the conservative groups left the 2018 elections stronger. This happened because the winning presidential candidate Jair Bolsonaro supported their agenda during the campaign and because the evangelical and pro-gun rights parliamentary 
groups gained members and strength. The business parliamentary group also managed to keep a large number of seats (DIAP, 2018).

\section{Liberal organizations and movements of middle and upper classes}

Liberal organizations and movements gathering the middle and upper classes played a fundamental role in spreading liberal ideas and leading demonstrations for the impeachment of President Dilma Rousseff in 2015 and 2016. Examples of these movements are Vem pra Rua (Come to the Street), Revoltados Online (Online Revolted), the Movimento Brasil Livre (MBL) (Free Brazil Movement). Across the country and in important parts of large cities such as Avenida Paulista (in São Paulo), and Copacabana Beach (Rio de Janeiro), protesters installed inflatable dolls with the images of President Lula da Silva (PT) dressed as prisoner, and President Dilma Rousseff, and performed symbolic burials of the authorities. Politicians such as Aécio Neves, Geraldo Alckmin, and José Serra, all from the party PSDB, were present at the demonstrations. There were numerous posters with messages such as "Fora PT" (Workers' Party get out), "Intervenção Constitucional (Artigo 142)" (claiming a military intervention, supposedly supported by article 142 of 1988 Brazilian Constitution), "Fora Comunismo" (No communism), and "Olavo de Carvalho tem razão" ("Olavo de Carvalho is right," referring to an ideologist with influence among the Brazilian far right-wing) (Folha de S. Paulo, 2015).

According to Camila Rocha, such movements in defense of economic liberalism are predominantly led by young university students and liberal professionals from the middle and upper classes. They have been coordinated through the Internet and using communication technologies since the creation of Orkut, in 2006. Organizations forming a network of ultraliberal think tanks such as Instituto Mises Brasil (IMB) and Instituto Millenium organizationally and financially supported these movements, contributing to training activists and building and institutionalizing an ultraliberal counter-public. These think tanks are maintained with funds offered by businesses such as Grupo Abril, Organizações Globo, Grupo Ultra, Grupo Gerdau, Grupo Évora. Finally, the emergence of the June 2013 demonstrations all over the country (which started with demands such as reducing public transportation prices and against corruption) represented an opportunity for this ultraliberal counter-public to gather unsatisfied sectors of the population. After President Rousseff's re-election in 2014, this counter-public worked to steer the protesters' agenda toward the president's impeachment (Rocha, 2019).

Thus, as of the 2016 democratic rupture, the rhetoric, discourses, and ideas envisaged by the epistemic communities were unified and later inserted in the constitu- 
tion based on a radical liberal-orthodox program, carried out by the governments of presidents Temer and Bolsonaro, as analyzed below.

\section{The political constitutionalization of the epistemic communities of fiscal austerity's ideas and the deconstitutionalization of social rights}

President Dilma Rousseff's impeachment in 2016 occurred amidst a severe economic crisis. Brazilian GDP fell 7.2\%, and the period 2015/2016 reflected the worst recession since 1948 (Valor Econômico, 2017), followed by a slow economic recovery. The president tried to get closer to the business community and the financial sector carrying out a tough fiscal adjustment. The result, however, was counterproductive (Pinho, 2019). The decline of workers' rights began during President Rousseff's second mandate in 2015, especially after the publication of provisional measures (MP) 664 and 665, without establishing a dialogue with society. The MPs put limits on the process of granting pensions for death (including in the case of public servants), sickness benefit, unemployment benefit, and salary bonus (Diap, 2018). Such restrictive measures were combated by sectors to the left of the president's own political party PT. Senator Paulo Rocha (Workers' Party - PT, representative from the State of Pará) was responsible for reporting the two MPs, acknowledged at the time: "It was a mistake for the government not to dialogue with the various sectors of workers" (Câmara dos Deputados, 2015).

The adverse economic situation and the support gained from the epistemological communities took Vice President Michel Temer to the presidency. President Rousseff's impeachment was, in fact, a parliamentary coup, adopting deceptive democratic legal procedures, and counting on the support of the National Congress, the Judiciary Branch, and the Public Ministry (Santos, 2017). The fall of Rousseff's government opened the path for the constitutionalization of the fiscal austerity regime and the deconstitutionalization of social rights enshrined during the period of Brazil's re-democratization. Temer's government approved the New Fiscal Regime (Constitutional Amendment 95/2016, derived from the constitutional amendment bill 55/2016), making it impossible to allocate enough resources to fund social policies within the standards established by the 1988 Constitution for 20 years. Once applied, the law will reduce the federal government's primary expenditure from around $20 \%$ of GDP in 2016 to something around 16\% of GDP by 2026 , or $12 \%$ in 2036, except for financial expenses related to the payment of debt interest. This policy of permanently reducing spending criminalizes the Keynesian countercyclical fiscal policy to face economic crises and surpasses the contractionary fiscal policies 
7. The President of the Chamber of Deputies, Rodrigo Maia (Federal Deputy from Rio de Janeiro, Democrats-DEM), worked to approve the reform. Maia said that Labor Courts should not exist, and that labor judges make irresponsible decisions (El País Brasil, March 23, 2017). of the US, the most liberal nation in the world. The US adopted the Budget Control Act, which is valid for approximately ten years and established by ordinary law. The legislation determines the reduction of the budgeted expenditures yearly, aiming to progressively decrease spending on social security, unemployment insurance, refundable tax credits, and veterans' benefits (Austeridade e Retrocesso, 2016; Rossi \& Dweck, 2016; 2018; Tavares \& Silva, 2020).

The outsourcing law and the labor reform ${ }^{7}$ defended by bankers, economists, businesspeople, and the mainstream press in constant editorials were implemented without a broad debate in society. The argument behind such changes was the need to overcome the archaism of the Consolidation of labor laws (CLT/1943) and render the country more competitive in the face of global demands. Some of the most important points changed with the labor reform were (1) agreements between employer and employee prevail over labor laws, (2) annual leave can be taken in chunks (rather than all in one go or divided into a maximum of two chunks of a minimum of ten days each, as in the previous law), (3) the possibility of establishing intermittent employment - paid on an hourly basis, and (4) the use of temporary work contracts for all companies activities, both essential and support activities ( $O$ Globo, 2016; Setubal, 2017).

Three years after the labor reform passed, empirical evidence shows a deterioration of public institutions responsible for labor law enforcement such as the Labor Court and the Ministry of Labor, which was extinguished under President Bolsonaro's government. The reform brought incentives for illegal contracts, increased the labor market's precariousness, informality, self-employment, and the number of discouraged workers (called desalentados) (Ipea, 2019; Nexo, November 07, 2019). Although the labor law changed substantially, with a strong tendency to erode the institutional legacy of Vargas (Getulio Vargas, president between 1930-1945, and from 1951 to 1954), based on the state corporatism that regulated capital/labor relations (Boschi \& Pinho, 2019a; 2019b), the government of President Temer was unable to approve the pension reform. Temer worked to continually disseminate throughout the country, in digital and mainstream media, the discourse of social security deficit or the notion of "reform today to guarantee tomorrow" (Exame, 2017).

Jair Bolsonaro's ultraliberal and conservative coalition, which took office in January 2019 , in addition to being able to approve the pension reform, reduce benefits substantially, and hamper access to social security and assistance benefits, has deepened the austerity measures of the previous government. Enormous power has been left in the hands of the Ministry of Economy, led by the ultraliberal economist 
Paulo Guedes, an exponent of the financial market and notorious follower of the 1970s Chicago School's assumptions. The government has been making drastic budget cuts and disrupting public policies on social participation, human and minority rights, education, foreign affairs, and the environment (Fleury \& Pinho, 2019).

\section{Final considerations}

This article was based on a robust theoretical-conceptual framework and empirical research, analyzing the construction of discourses and the institutionalization of ideas of epistemic communities of fiscal austerity and the impact of such ideas on the welfare state. The study demonstrated the operationalization of the epistemic communities' ideas and how they were inserted in the Brazilian constitution, starting with a parliamentary coup in 2016 and followed by constitutional amendments put forward by the liberal-conservative coalition formed in the governments of presidents Temer and Bolsonaro.

After the first mandate of President Lula da Silva, several segments of society started to assertively disseminate their ideas and assumption on how Brazil should manage its macroeconomy and formulate and implement public policies. The sectors exposing and advocating ideas in the public sphere were academia, political parties and institutions with a liberal-conservative profile, orthodox economists, mainstream press, the oligopolistic media, industrial entrepreneurs, the financial market, university students, and liberal professionals from the middle and upper classes. In this period, President Lula da Silva adopted a pro-developmentalist approach for the macroeconomic policy even though maintaining fiscal austerity policies as a structural constriction imposed by financial globalization. It is worth noting that, as of 2014, there was a significant drop in the number of policymakers in parliamentary fronts related to unions or workers. In contrast, the number of liberal-conservative party coalition in the Congress increased, with parliamentary fronts focused on religious groups' interests (particularly Neo-Pentecostal), pro-gun rights, and defense of agribusiness sectors, and refractory to universal social policies, human rights, and environmental protection.

The epistemic communities' agenda acquired a higher level of dissemination and radicalization during President Rousseff's government, leading to a fracture of the political-economic coalition supporting her administration. It was in this period, in 2015, that the then Vice President Michel Temer launched the austerity program Uma ponte para o futuro (a bridge to the future), consolidating these ideas. This study demonstrated how this agenda was embodied in political practice, emphasizing the deep fiscal austerity started during Rousseff's second term. The research 
was based on the hypothesis that the establishment of an epistemic community of fiscal austerity - from the end of Lula da Silva's first mandate, in 2006, until the impeachment of Rousseff in 2016 - emphatically disseminated the neoliberal assumption that the 1988 Constitution is no longer compatible with the capacity of the Brazilian state budget. The study fills an important gap in the literature, presenting, in an interdisciplinary way, how the epistemic communities operationalized the liberal-orthodox and monetarist discourse until its institutionalization in public policies by a liberal-conservative political-economic coalition committed to the intensification of fiscal discipline. A political economy of public policies was carried out, bringing together the dimensions of the ideas' influence on the implementation of welfare policies, the political economy of development, and the political-economic coalitions supporting austerity measures.

The different epistemic communities share intersubjective understandings, have a converging mode of knowledge, share reasoning patterns, have a political project based on similar values, share causal beliefs and associated discursive practices, and converge in their commitment to knowledge production and application. As epistemic communities connect globally, control over knowledge and information is an essential dimension of power. The diffusion of new ideas and information can lead to new behavior patterns and be an important determinant of international political coordination. They share the same worldview (or episteme) and constitute channels through which new ideas circulate from societies to governments, as well as from country to country, and help to formulate public policies (Haas, 1992).

Based on the theoretical and conceptual framework developed by Peter Haas, a pioneer in formulating the concept of epistemic communities, this study puts forward the argument that epistemic communities of fiscal austerities have their particularities but widely share a belief on fiscal austerity. They massively spread ideas in line with the free market, individual freedom, free initiative, and oppose state intervention in the economy. They seek to influence the formulation of public policies toward a project of power based on the intensification of pro-market reforms, even if this means constriction of public spending, the deconstitutionalization of social rights, and sacrifice for the majority of the population. This article shows that, within the scope of political institutionality, the broad political-economic and societal coalition around the epistemic communities of fiscal austerity has managed to convert their ideas into public policies. Their interests are represented by an authoritarian, liberal-conservative, and reactionary project of power endorsed in the 2018 presidential elections in Brazil. 


\section{References:}

ABRANCHES, Sérgio. Presidencialismo de coalizão: raízes e evolução do modelo político brasileiro. São Paulo: Companhia das Letras, 2018.

ARRETCHE, Marta; MARQUES, Eduardo; FARIA, Carlos A. P. de. Considerações finais - Produzindo mudanças por estratégias incrementais: a inclusão social no Brasil pós-1988. In: ARRETCHE, Marta; MARQUES, Eduardo; FARIA, Carlos Aurélio Pimenta de (Orgs.). As políticas da política: desigualdades e inclusão nos governos do PSDB e do PT. São Paulo: Editora Unesp, 2019.

AUSTERIDADE e RETROCESSO: Finanças Públicas e Política Fiscal no Brasil. São Paulo: Fórum, 21; Fundação Friedrich Ebert Stiftung (FES); GT de Macro da Sociedade Brasileira de Economia Política (SEP); Plataforma Política Social, setembro 2016. Retrieved October 22, 2019, from: <http://plataformapoliticasocial.com.br/wp-content/uploads/2016/10/Doc-AUSTERIDADE_final_ok.pdf>.

BASTOS, Pedro P. Z. Ascensão e crise do governo Dilma Rousseff e o golpe de 2016: poder estrutural, contradição e ideologia. Revista de Economia Contemporânea, Número Especial, p. 1-63, 2017. Retrieved August 02, 2020, from: <https://www. scielo.br/scielo.php?script=sci_arttext\&pid=\$141598482017000200209\&lng=pt\&tlng=pt>.

BOSCHI, Renato; PINHO, Carlos E. S. Crisis and austerity: the recent trajectory of capitalist development in Brazil. Contemporary Politics, v. 25, n. 3, p. 292-312, 2019a. Retrieved June 02, 2020, from: <https://www.tandfonline.com/doi/fuII/10.1080/13569775.2018.1555783?src=recsys $>$.

BOSCHI, Renato; PINHO, Carlos E. S. Crise fiscal, pensamento empresarial e financeirização no Brasil: a desconstrução da ordem corporativa no século XXI. In: GIACALONE, Rita (Ed.). Pensamiento empresarial latinoamericano en el siglo XXI. "Colección Pensamiento Global". Bogotá: Editorial Universidad Cooperativa de Colombia, 2019b.

CÂMARA DOS DEPUTADOS. Relator: governo errou ao não dialogar com centrais sobre MP do seguro-desemprego. April 07, 2015. Retrieved August 03, 2020, from: <https://www.camara.leg.br/noticias/454854-relator-governo-errou-ao-nao-dialogar-com-centrais-sobre-mp-do-seguro-desemprego>.

CAMPELLO, Daniela. The politics of market discipline in Latin America: globalization and democracy. Cambridge: Cambridge University Press, 2015. 
CARVALHO, Laura. Valsa brasileira: do boom ao caos econômico. São Paulo: Todavia, 2018.

CASTELLS, Manuel. A sociedade em rede. São Paulo: Paz e Terra, 1999.

DAVIS, Gerald F.; KIM, Suntae. Financialization of the economy. Annual Review of Sociology, v. 41, p. 203-221, 2015. Retrieved August 06, 2020, from: <https://www. annualreviews.org/doi/pdf/10.1146/annurev-soc-073014-112402>.

DEPARTAMENTO INTERSINDICAL DE ASSESSORIA PARLAMENTAR (DIAP). Radiografia do novo Congresso - Legislatura 2019-2023. Brasília: Diap, Dez. 2018. Retrieved August 01, 2020 from: <https://www.diap.org.br/index.php/publicacoes/ finish/41-radiografia-do-novo-congresso/4045-radiografia-do-novo-congresso-legislatura-2019-2023-fevereiro-de-2019>.

DOWBOR, Ladislau. A Era do Capital Improdutivo: a nova arquitetura do poder dominação financeira, sequestro da democracia e destruição do planeta. São Paulo: Autonomia Literária, 2017.

EL PAÍS BRASIL. Câmara aprova terceirização para todas as atividades. Entenda o que muda, March 23, 2017. Retrieved September 09, 2019 from: <https://brasil. elpais.com/brasil/2017/03/21/politica/1490127891_298981.html>.

ERBER, Fábio S. As convenções de desenvolvimento no governo Lula: um ensaio de economia política. Revista de Economia Política, v. 31, n. 1, p. 31-55, Jan.-Mar. 2011. Retrieved August 08, 2020 from: <http://www.scielo.br/pdf/rep/v31n1/a02v31n1. pdf $>$.

O ESTADO DE S. PAULO. Taxa básica de juros do Brasil ainda é uma das mais altas do mundo. 03 Jun. 2020. Retrieved August 03, 2020 from: <https://einvestidor.estadao.com.br/mercado/juros-altos-brasil-mundo/>.

Cunha programa 'pauta-bomba' de R\$ 207,1 bilhões. 24 Fev. 2016. Retrieved August 01, 2020 from: <https://politica.estadao.com.br/noticias/geral,cunha-programa-pauta-bomba-de-r-207-1-bilhoes,10000018003>.

Congresso eleito é o mais conservador desde 1964, afirma Diap. 06 Out. 2014. Retrieved January 29, 2020 from: <https://politica.estadao.com. $\mathrm{br} /$ noticias/eleicoes, congresso-eleito-e-o-mais-conservador-desde-1964-afirma-diap,1572528>.

EXAME. Em discurso de Natal, Temer defende reforma da Previdência. 25 Dez. 2017. Retrieved August 12, 2020 from: <https://exame.com/brasil/em-discurso-de-natal-temer-defende-reforma-da-previdencia/>. 
FLEURY, Sonia; PINHO, Carlos. E. S. La deconstrucción de la democracia social y de la ciudadanía urbana en Brasil. Medio Ambiente y Urbanización, v. 90, n. 1, p. 271304, Jun. 2019. Retrieved August 21, 2020 from: <https://www.ingentaconnect. com/contentone/iieal/meda/2019/00000090/00000001/art00014>.

Authoritarian governments and the corrosion of the social protection network in Brazil. Revista Katálysis, v. 21, n. 1, p. 29-42, Jan./Abr. 2018. Retrieved August 12, 2020 from: <https://www.scielo.br/scielo.php?script=sci_arttext\&pi$d=$ S1414-49802018000100029>.

FOLHA DE SÃO PAULO. Movimentos anti-PT levarão boneco de Lula para desfile em que Dilma irá. 06 Set. 2015. Retrieved August 03, 2020 from: <https://www1.folha. uol.com.br/poder/2015/09/1678175-movimentos-anti-pt-levarao-boneco-de-lulapara-desfile-em-que-dilma-ira.shtml?mobiles.

Editorial: Última chance. 13 Set. 2015. Retrieved August 02, 2020, from: <https://m.folha.uol.com.br/opiniao/2015/09/1681108-ultima-chance.shtml>.

G1. PSDB pede ao TSE auditoria para verificar 'lisura' da eleição. 30 Out. 2014. Retrieved August 03, 2020 from: <http://g1.globo.com/politica/noticia/2014/10/ psdb-pede-ao-tse-auditoria-para-verificar-lisura-da-eleicao.html>.

HAAS, Peter. Introduction: epistemic communities and international policy coordination. International Organization. Knowledge, Power, and International Policy, v. 46. 1, 1992. Retrieved March 26, 2019, from: <https://www.unc.edu/ fbaum/ teaching/articles/IO-1992-Haas.pdf>.

INSTITUIÇÃO FISCAL INDEPENDENTE (IFI). Relatório de Acompanhamento Fiscal, n. 8, Set. 2017. Retrieved September 15, 2017 from: <http://www2.senado.leg.br/ bdsf/bitstream/handle/id/531520/RAF8_SET2017.pdf>.

INSTITUTO DE PESQUISA ECONÔMICA APLICADA- IPEA. Carta de Conjuntura, n. 42, 1ㅇtrimestre 2019. Retrieved August 03, 2020 from: <http://www.ipea.gov.br/portal/images/stories/PDFs/conjuntura/190320_cc_42_mercado_de_trabalho.pdf>.

KERSTENETZKY, Celia Lessa. Foi um pássaro, foi um avião? Redistribuição no Brasil no século XXI. Novos Estudos Cebrap, v. 36, n. 2, p. 15-34, 2017. Retrieved September 15, 2017 from: <http://novosestudos.uol.com.br/produto/108/>.

LADI, Stella; LAZAROU, Elena; HAUCK, Juliana. Brazilian think tanks and the rise of austerity discourse. Policy and Society, v. 37, n. 2, p. 222-242, 2018. Retrieved March 19, 2020, from: <https://www.tandfonline.com/doi/full/10.1080/14494035 .2017.1397396> 
LOUREIRO, Maria Rita; SANTOS, Fábio Pereira dos; GOMIDE, Alexandre de Ávila. Democracia, arenas decisórias e política econômica no governo Lula. Revista Brasileira de Ciências Sociais (RBCS), v. 26, n. 76, Jun. 2011. Retrieved August 20, 2020, from: <https://www.scielo.br/pdf/rbcsoc/v26n76/04.pdf>.

MENDES, Marcos. Por que o Brasil cresce pouco? Desigualdade, democracia e baixo crescimento no país do futuro. Rio de Janeiro: Elsevier, 2014.

NEXO. Como ficou o emprego 2 anos após a reforma trabalhista. 07 Nov. 2019. Retrieved August 03, 2020, from: <https://www.nexojornal.com.br/expresso/2019/11/07/Como-ficou-o-emprego-2-anos-ap\%C3\%B3s-a-reforma-trabalhista>.

NÓBREGA, Mailson da. Construção e desmonte das instituições fiscais. In: SALTO, Felipe; ALMEIDA, Mansueto (Orgs.). Finanças públicas: da contabilidade criativa ao resgate da credibilidade. Rio de Janeiro: Record, 2016.

O GLOBO. Editorial: A grande crise fiscal deixada pelo lulopetismo. 01 Abr. 2017. Retrieved September 13, 2017 from: <https://oglobo.globo.com/opiniao/a-grande-crise-fiscal-deixada-pelo-lulopetismo-21144748>.

Editorial: Sociedade paga a conta do dirigismo de Lula e Dilma. 23 Fev. 2017. Retrieved April 04, 2020, from: <http://oglobo.globo.com/opiniao/sociedade-paga-conta-do-dirigismo-de-lula-dilma-20967063>.

Editorial: Reforma trabalhista preserva e cria empregos. 17 Jul. 2016. Retrieved August 19, 2017, from: <https://oglobo.globo.com/opiniao/reforma-trabalhista-preserva-cria-empregos-19728022>.

Fiesp e Firjan defendem impeachment de Dilma. 17 Mar. 2016. Retrieved August 02, 2020, from: <https://oglobo.globo.com/economia/fiesp-firjan-defendem-impeachment-de-dilma-18902113>.

Lula anuncia corte de R\$ 14 bi, atingindo área social, e superávit de 4,25\% do PIB. 17 Set. 2015. Retrieved August 02, 2020, from: <http://acervo.oglobo.globo.com/em-destaque/lula-anuncia-corte-de-14-bi-atingindo-area-social-superavitde-425-do-pib-17509677>.

PINHO, Carlos E. S. The responses of the authoritarian national developmentalism to the structural economic crisis (1973-1985). Brazilian Journal of Political Economy, v. 40, n. 2, p. 411-431, Abr./Jun. 2020. Retrieved August 05, 2020, from: <https:// www.scielo.br/scielo.php?script=sci_arttext\&pid=S0101-31572020000200411\&ln$\mathrm{g}=e n \& \mathrm{nrm}=\mathrm{iso}>$. 
. Planejamento estratégico governamental no brasil: autoritarismo e democracia (1930-2016). Curitiba: Appris, 2019.

ROBERTS, K. M. Is social democracy possible in Latin America? Nueva Sociedad, n. 217, p. 1-11, Set.-Out. 2008. Retrieved August 03, 2020, from: <https://nuso.org/ articulo/es-posible-una-socialdemocracia-en-america-latina/>.

ROCHA, Camila. Imposto é roubo! A Formação de um contrapúblico ultraliberal e os protestos pró-impeachment de Dilma Rousseff. Dados - Revista de Ciências Sociais, v. 62, n. 3, p. 1-42, 2019. Retrieved August 01, 2020, from: <http://www.scielo.br/ pdf/dados/v62n3/0011-5258-dados-62-3-e20190076.pdf>.

ROSSI, Pedro; DWECK, Esther. O teto de gastos federais deve ser revisto? SIM, Folha de S. Paulo, 23 Jun. 2018.

Impactos do Novo Regime Fiscal na saúde e educação. Cad. Saúde Pública, v. 32, n. 12, 2016. Retrieved March 19, 2019, from: <http://www.scielo.br/pdf/csp/ v32n12/1678-4464-csp-32-12-e00194316.pdf>.

SALTO, Felipe; ALMEIDA, Mansueto. Introdução: responsabilidade fiscal é a chave para voltar a crescer. In: SALTO, Felipe; ALMEIDA, Mansueto (Orgs.). Finanças públicas: da contabilidade criativa ao resgate da credibilidade. Rio de Janeiro: Record, 2016

SALVADOR, Evilasio da Silva. O desmonte do financiamento da Seguridade Social em contexto de ajuste fiscal. Serviço Social \& Sociedade, n. 130, p. 426-446, Set.Dez. 2017. Retrieved August 10, 2020, from: <https://www.scielo.br/scielo.php?script=sci_arttext\&pid=S010166282017000300426\&lng=en\&nrm=iso\&tlng=pt>.

SANTOS, Wanderley Guilherme dos. A democracia impedida: o Brasil no século XXI. Rio de Janeiro: FGV Editora, 2017.

SCHMIDT, Vivien. A. Discursive institutionalism: the explanatory power of ideas and discourse. Annual Review of Political Science, v. 11, p. 303-326, 2008.

SETUBAL, Roberto. A importância da reforma trabalhista. Folha de S. Paulo, 02 Jul. 2017. Retrieved August 16, 2017, from: <http://www1.folha.uol.com.br/opiniao/2017/07/1897671-a-importancia-da-reforma-trabalhista.shtml>.

STREECK, Wolfgang. O retorno dos reprimidos como início do fim do capitalismo neoliberal. In: APPADURAI, Arjun et alii (Orgs.). A grande regressão: um debate internacional sobre os novos populismos e como enfrentá-los. São Paulo: Estação Liberdade, 2019. 
TAVARES, Francisco; SILVA, Gustavo. A ciência política brasileira diante do novo regime fiscal: para uma agenda de pesquisas sobre democracia e austeridade. Dados Revista de Ciências Sociais, v. 63, n. 2, 2020. Retrieved August 05, 2020, from: <https:// www.scielo.br/scielo.php?script=sci_arttext\&pid=S0011-52582020000200203>.

TOLLINI, Hélio M. Repensando a gestão das finanças públicas no Brasil. In:SALTO, Felipe; ALMEIDA, Mansueto (Orgs.). Finanças públicas: da contabilidade criativa ao resgate da credibilidade. Rio de Janeiro: Record, 2016.

Uma ponte para o futuro. Fundação Ulisses Guimarães, PMDB, 29 Out. 2015. Retrieved February 11, 2016 from: <http://pmdb.org.br/wp-content/uploads/2015/10/ RELEASE-TEMER_A4-28.10.15-Online.pdf>.

VALOR ECONÔMICO. PIB do Brasil cai 7,2\% em dois anos, pior recessão desde 1948. 07 Mar. 2017.

WEBER, Max. A ética protestante o "espírito" do capitalismo. São Paulo: Companhia das Letras, 2004. 